\title{
studia
}

\section{MiROSŁAW MRÓZ}

\section{Filozofia Franciszka Sawickiego}

Ksiądz Franciszek Sawicki (1877-1952) to bezsprzecznie jeden z największych filozofów, teologów i apologetów Pomorza Nadwiślańskiego, swoistego rodzaju filozoficzny genius loci. Filozoficzna myśl Sawickiego jest bardzo rozległa, prowadzi od klasycznych rozważań metafizycznych rozwijanych zwłaszcza w kontekście filozofii religii, poprzez swoistego rodzaju „filozofię życia”, aż po intelektualne poszukiwania $\mathrm{w}$ przestrzeni nowszych nurtów myśli europejskiej, egzystencjalizmu i personalizmu. O znaczeniu myśli Sawickiego pisano niejednokrotnie, i to w obszarze różnych dyscyplin filozoficznych i teologicznych, prezentując go jako historyka filozofii, teoretyka poznania czy też filozofa „katolickiego”, który w poszukiwaniu prawdy ogólnej potrafi po mistrzowsku jednać różne aspekty, często wręcz przeciwne, we wspólną całość. Najczęściej mimo wszystko, już w okresie dwudziestolecia międzywojennego uważany był za najważniejszego personalistę chrześcijańskiego. Do polskiej szkoły personalizmu zalicza go Leszek Kołakowski, ks. Stanisław Kowalczyk, ks. Marian Rusecki. Inny znawca tej tematyki, ks. Czesław Bartnik, sugeruje wręcz, że Franciszka Sawickiego należy postawić w szeregu eksponowanych personalistów neotomistycznych, takich jak: Jacques Maritain, Peter Wust, Étienne Gilson, Maurice Nédoncelle, a w Polsce Jacek Woroniecki, Wincenty Granat, Mieczysław Gogacz, Mieczysław A. Krąpiec, Karol Wojtyła, Tadeusz Styczeń, Andrzej Szostek. U Sawickiego sytuacja jest jednak na tyle specyficzna, że jego „filozofia osobowość”, zaliczana do personalizmu polskiego, bezsprzecznie wiele zawdzięcza personalizmowi niemieckiemu, z powodu które- 
go czasami bywa on włączany także do grona myślicieli niemieckich. Sawicki żyje bowiem na ówczesnym pograniczu niemiecko-polskim, publikuje zarówno w języku niemieckim, jak i polskim. Swoją naukową podróż rozpoczyna we Fryburgu Badeńskim (1900-1903), gdzie słucha wykładów wielu znanych filozofów niemieckich i gdzie swoje studia uwieńczył rozprawą doktorską Der Prediger, Schopenhauer und Edward v. Hartmann oder Biblischer und moderner Pessimismus (1903), napisaną u znanego filozofa i teologa Karola Braiga. Personalizm Franciszka Sawickiego zawiera dużą dozę inności i własnych osobistych odniesień związanych z jego wykształceniem we Fryburgu Badeńskim i bezsprzecznie $\mathrm{z}$ bardzo mocnym zakorzenieniem $\mathrm{w}$ środowisku filozofii niemieckiej. Bez wątpienia swoje inspiracje ontologiczne zaczerpnął od promotora swojej pracy doktorskiej prof. Karla Braiga (1853-1923), tego samego, z którego myśli będzie czerpał także Martin Heidegger, zwłaszcza $\mathrm{w}$ pierwszym okresie swojej filozofii. Pod wpływem innego wybitnego profesora z uniwersytetu we Fryburgu Heinricha Rickerta (1863-1936) zwróci się ku fenomenologii i filozofii wartości. Personalizm reprezentowany przez Sawickiego ucieka zapewne od ścisłego racjonalizmu, nie nosi on znamion przesadnego dogmatyzmu, parcelacji i bezdziejowości. Jego personalizm nie jest jakimś systemem zamkniętym, doktryną już postulowaną i opracowaną raz na zawsze, ale szerokim widnokręgiem świata osoby i wspólnoty, która - wychodząc od ich adekwatnego zrozumienia - otwiera się także na transcendencję, przestrzeń religii i wiary. Sawicki w personalizmie zwraca się $\mathrm{w}$ kierunku łączenia elementów tomizmu $\mathrm{z}$ augustynizmem. Jest przekonany, że filozofia chrześcijańska „opiera się w pierwszej linii na Tomaszu z Akwinu, ale w Tomaszu żyje teologia augustyńska” (U źródeł chrześcijańskiej myśli filozoficznej, s. 76). Profil tomistyczny wyraża się w tym, że Sawicki widzi konieczność rozważenia egzystencjalnych problemów ludzkiego bytu (życie, cierpienie, śmierć), profil zaś augustyński w tym, że eksponuje aktywność woli i sfery emocjonalnej, oraz wreszcie aksjologiczny, bo ukazuje naczelną rolę wartości. W teorii poznania głosi „postulat zaufania” do rozumu, wskazując na znaczenie woli i uczuć w procesie poznawczym. Podkreśla transcendencję człowieka wobec świata, atrybut wolności, relacje wobec społeczności, egzystencjalne problemy cierpienia i śmierci. Jego personalizm nie ogranicza się do ontologicznej analizy osoby ludzkiej, lecz uwzględnia również aksjologiczne i społeczne aspekty świata ludzkiego.

Swymi pracami w języku niemieckim, m.in.: Wert un Würde der Perönlichkeit in Christentums (1906), Das Problem der Perönlichkeit und des Übermenschen (1909), Die Wahrheit des Christentums (1911), Politik und Moral (1917), 
Geschichtsphilosophie (1920), Die Gottesbeweise (1926), zyskał uznanie także w kołach niemieckich teologów i filozofów katolickich. Zaliczany był już za swojego życia do czołowych myślicieli chrześcijańskiej Europy. Wydawnictwo F. Meinera w Lipsku, publikując cykl monografii wybitnych uczonych i filozofów, umieściło również F. Sawickiego w panteonie wybitnych przedstawicieli myśli katolickiej (1927). Zapraszany był z wykładami do różnych miast w Polsce i za granicę, rzadko jednak opuszczał swoje ukochane Pomorze Nadwiślańskie. Za publikacje o narodowym socjalizmie był ostro jednak atakowany przez prasę hitlerowską, np. Nowoczesne teorie rasowe (1934), Religia narodowa i rasowa (1935), Rasa i światopogląd (1939). Kiedy Stolica Apostolska wyznaczyła go na biskupa diecezji gdańskiej (1938), a tej nominacji sprzeciwił się Senat Wolnego Miasta Gdańska, to Watykan wycofał swoją kandydaturę. Droga życiowa F. Sawickiego ściśle związana jest z Wyższym Seminarium Duchownym w Pelplinie, gdzie wykładał filozofię od chwili powrotu ze studiów, aż po ostatnie dni swojego życia. Ważna w jego naukowym curriculum jest także jego czynna przynależność do Towarzystwa Naukowego w Toruniu, gdzie przez cały okres międzywojenny sprawował funkcję przewodniczącego Wydziału Teologicznego. Pod koniec życia, w 1952 roku, otrzymał doktorat honoris causa, nadany przez Wydział Filozofii Chrześcijańskiej Katolickiego Uniwersytetu Lubelskiego. Uroczystość nadania tego tytułu odbyła się jeszcze w czasach dużego nasilenia się prześladowań wszystkiego, co nie było zgodne z orientacją marksistowską, a co wskazuje na niezaprzeczalną wielkość myśli F. Sawickiego przekraczającą jakiekolwiek granice i podziały. Filozofię Franciszka Sawickiego charakteryzuje fakt, że pozostaje ona jak najbardziej rodzimą myślą pomorską, a kształtując się w obszarze wzajemnego przenikania się myśli i kultury polskiej i niemieckiej, zawiera znamiona nowe i wartościowe, zarówno w swojej treści, jak i formie. W tym sensie jest w pełni otwarta i prawdziwie europejska, tu, gdzie uniwersalizm chrześcijański ujawnia swoją szczególną moc syntezy. Wykaz jego prac jest bardzo obszerny, liczy wiele pozycji książkowych, artykułów i recenzji (bibliografia zebrana przez ks. H. Mrossa podaje 457 pozycji), m.in.: Katolische Kirche und sittliche Persönlichkeit (1907), Der Sinn des Lebens (1913), Lebensanschauungen moderner Denker (1919), Das Ideal der Persönlichkeit (1922), Lebensanschauungen alter und neuer Denker (1923), Philosophie de Liebe (1924), Die vier Lebensalter (1929), Dusza nowoczesnego człowieka (1931), Dlaczego wierzę? (1935), Filozofia życia (1936), Życie ludzkie (1936), Fenomenologia wstydliwości (1938), Katolicyzm jako religia osobowości i społeczności (1939), Osobowość chrześcijańska (1947), U źródeł chrześcijańskiej myśli filozoficznej (1947), Deus caritas est (1948). 